\title{
For My Aunt Florence Who When Praying Gives God Not Only Her Friends' Names but Also Their Addresses · Nancy Sullivan
}

Sure as the brakes on a Buick,

God is a mighty power.

Omnipotent, sure as there's light in the bulbs.

His wattage is wonderful.

But omniscience is a mackinaw we've buttoned him into.

(There must, surely there must somewhere

Be someone who knows everything!)

After the Fall, God rose as the fall guy.

Aunt Florence, knowing without knowing, With a leatherette address book, both breviary And Bible, directed God exactly giving house Number, avenue or boulevard, sometimes even The phone number: the Karl Sunderlunds on 4 Brave Drive in Minneapolis, Minnesota; Alice Damark in Madison, WisconsinPhone: (608) 238-8246;

Leo Spooner, 32 Farewell Street, Newport, Rhode Island, Zip code 02840.

However else would he find them?

After all, the Sunderlunds were Lutherans and Alice a Jew. She uttered this geography in a new litany To lure him. She became his faithful navigator.

How did he keep us straight before he'd found her?

Let alone find us way out in Topeka, or up in the Catskills, to say nothing of Brooklyn, Ethiopia, Brazil, Scarsdale, London, the Bronx? 
Let the mapmen honor you, Aunt Florence, lady of locales, Tracer of those troubled by needs they'd not dreamed of. And may the God in whose employ you labor Find you always, especially when you've moved down Into that last dirty apartment under the ground. 